\title{
Markets, Choice and Agency
}

\author{
Timothy Fowler ${ }^{1}$
}

Published online: 3 November 2015

(C) The Author(s) 2015. This article is published with open access at Springerlink.com

\begin{abstract}
John Tomasi's Free Market Fairness (2012) introduces several powerful arguments in favour of a novel and surprising thesis: the best way to realize Rawls's principles of justice is a free market society, rather than the arrangements that Rawls himself believed would best promote justice. In this paper, I adduce three arguments against Tomasi. First, I suggest that his view rests on a faulty understanding of what constitutes conventional property rights. Second, I argue that many market solutions generate choices which are not valuable ones for the agent to have to make. Third, I show that many choices created by the market systems Tomasi favours create the illusion that citizens are making their own choices when in fact they are not. I suggest that taken together these three arguments are sufficient to defend Rawlsian institutional arrangements against Tomasi's challenge.
\end{abstract}

Keywords John Tomasi · Free market fairness - Equality of opportunity

\section{Introduction}

Recent debates in political theory appear to suggest that the primary question of politics is the distribution of various socially produced goods. The views of egalitarians, sufficientarians and prioritraians (and of course responsibility sensitive prioritarians, shift sufficientarians and any number of hybrid views) offer an array of possible metrics for ranking distributive outcomes (see, for instance, Parfit 1997; Shields 2012; Temkin 2003). However, while these distributive questions are obviously important, they do not constitute the whole of politics. Politics is also the study of how these various goods are produced and political theorists had better

Timothy Fowler

tim.fowler@bristol.ac.uk

1 Sociology, Politics and International Studies, University of Bristol, Bristol, UK 
come up with accounts of which mode of production is most normatively desirable if they expect to offer a complete account of the conditions of a just society.

In his recent work, Free Market Fairness (2012), John Tomasi addresses this question of production and provides a powerful defence of market capitalism. While Tomasi's argument draws upon the distributional effects of capitalism it cannot be reduced to a distributional claim. Markets are to be commended not (merely) because they allocate goods in a fair and just manner, or because they tend to enlarge the total stock of goods. Instead, Tomasi defends market societies on the basis that they better enable citizens to become responsible self-authors. In this way, Tomasi offers a radically different defence of market economics from those that are familiar within the literature. Standardly, defences of markets have come from libertarians, who endorse the claim that markets are necessary for the just distribution of goods since redistribution violates people's rights, or from classical liberals who argue that markets are the only efficient way to govern the incredible complexity of modern social life. ${ }^{1}$ In contrast, Tomasi's defence of markets from self-governance draws upon ideals most commonly associated with left wing modes of production. Most notably, Tomasi suggests that a free market can be justified by reference to the moral ideal of justice as fairness developed by Rawls (1971). The central core of Tomasi's argument is that market-based societies allow individuals to develop as independent agents, and in so doing develop their interest in the two Rawlsian moral powers, the Reasonable and the Rational.

In this paper I assess the link between markets and political agency. I suggest that several of Tomasi's arguments are persuasive, in particular the link between entrepreneurship and political development. However, I also suggest that the link between markets and agency is less close than Tomasi believes. I outline several reasons to think that often a market solution will undermine the ability of citizens to develop as citizens, and explore the connotations of these arguments for thinking about which institutions best realise justice.

In brief, I argue that a social safety-net including (but not limited to) universal provision of healthcare, education and a basic income cannot generally be considered a threat to citizens' abilities to live independent and autonomous lives. The result of this argument is to suggest that while Tomasi's arguments are rich and interesting, they do not provide support for a laissez-faire economy. Instead, they suggest that the most promising forms of economic production are those that combine a culture of entrepreneurship and economic growth with state-based institutions to reduce the need to make choices in certain domains. Before outlining these substantive arguments, I briefly counter a mistaken attack by Tomasi on a widely held liberal-egalitarian conception of property rights. The purpose of this discussion is to outline the scope and status of economic liberties of ownership compared to other basic liberties such as freedom of association or the right to bodily integrity or the right to vote.

\footnotetext{
1 The classic defence of the rights-based approach is Robert Nozick, Anarchy State and Utopia (1974). The argument from social complexity is most notably associated with Friedrich Hayek.
} 


\section{Property Rights and the Basic Liberties}

A prominent defence of free markets begins with a natural conception of property rights. Lockeans such as Robert Nozick argue that humans can come to have moral claims upon pieces of the external world and that the existence of these rights provides a powerful reason to oppose state redistribution of wealth (Nozick 1974). The Lockean account rests these property rights upon rights individuals have of selfownership. On this account individuals acquire property rights via the application of their owned labour, and can rightfully claim the fruits of this labour. This account has been subjected to two broad kinds of critique. One rebuttal suggests that while individuals are indeed self-owners, this moral fact does not support free market politics. This reply, in different ways, is offered by left libertarians such as Otsuka (2005), Steiner (1977), and by Cohen (1986). The second response, offered by many liberal egalitarians, is to suggest that whatever other natural rights people might have, they cannot possess such claims over the external world. This is because property is a social convention, and it makes no sense to claim a pre-societal right to property.

Interestingly, Tomasi broadly endorses this liberal egalitarian critique of Lockean libertarianism. However he denies that its rejection has the salience social democrats usually claim. His target in this argument is primarily Murphy and Nagel's Myth of Ownership (2002). Murphy and Nagel claim that since property is conventional, no tax regime could conceivably violate property rights. On their view any individual's claim on property is to their post-tax, rather than pre-tax income. This is because taxes are themselves part of the conventions which create and sustain property rights, "private property is a legal convention, defined in part by looking at the tax system, therefore the tax system cannot be evaluated by looking at its impact on private property, conceived as something that has independent existence and validity' (Murphy and Nagel 2002, p. 6). Tomasi disagrees with this analysis. He argues that there is no relevant difference between property rights and other basic rights. The worry Tomasi raises with Murphy and Nagel's view is that all basic liberties are socially constructed rules (Tomasi 2012, p. 70). Given this, he argues that Murphy and Nagel are committed to the absurd suggestion that if tax laws cannot violate property rights then no laws can ever violate citizens' basic rights.

However, I believe Tomasi misunderstands Murphy and Nagel. One problem with Tomasi's response is that he places a good deal of weight on the observation that on a market democratic conception property rights need not be absolute. He writes 'for us the important point is that when applied to nonabsolutist defences of thick economic liberty, this argument from legal convention quickly disappears' (Tomasi 2012, p. 70). Indeed, Tomasi appears to suggest that libertarians are committed to treating property rights as absolutes, writing 'if strict libertarians count property rights as absolutes, market democracy does not think of the economic liberties in this way' (Tomasi 2012, p. 90). However, the distinction between absolute and defeasible property rights is something of a red herring in this debate. There is nothing in the libertarian account which commits them to believing that in being natural and grounded in self-ownership property rights should be therefore be absolute. Indeed, even Nozick who is the target of Tomasi's above comment considers including 
'catastrophe' clause which allows bad consequences of sufficient weight to override legitimate property claims (Nozick 1974, p. 30). Many right and left libertarians permit the overriding of property claims in much less dire circumstances. ${ }^{2}$

Instead of distinguishing between absolute and defeasible property rights, the proper distinction between natural rights theorists and conventional theorists is whether a property claim is an input into deciding which scheme of property laws to enforce or if it is purely an output of these laws. To illustrate the second (conventionalist) possibility, consider an example of a gatherer tribe picking berries. This tribe lives near a single large berry bush. While the berry bush can provide enough for all, its supplies are not abundant. Thus the tribe must come up with some way to control who gets to eat which berries. On one proposal, gatherers may pick as many berries as they like and have ownership claims to any berries they pick. However, this scheme will lead to a tragedy of the commons scenario and the eventual death of the tribe. Instead, the tribe could opt for a system by which gatherers can take up to 100 berries, but no more. This prevents a tragedy of the commons, but is problematic since on some days gatherers end up in the wrong place and get no berries, whereas on others they hit their limit easily. This prompts a third possibility in which gatherers can pick up 200, but must give half of their crop to a communal pot to distribute to those who are unlucky.

On each of these differing schemes gatherers have very different property claims. On the second proposal it is simply not true to say that people have any property claim at all to berries they picked after taking 100. Thus the tribal elders do them no wrong at all if they take these excess berries off a hunter. The claim that individuals have no claim to goods they wrongly acquire forms part of the Lockean treatment of natural property. On Locke's view people have no claim to acquisitions which violate the proviso that they must leave 'enough and as good for others' (Locke 2008, p. 20). Acquisitions which do not meet this proviso do not even generate valid property claims which are then overridden; they simply have no moral status at all. In precisely the same way, on the final scheme gatherers have no property claim on their entire crop of berries. Instead the process of the elders taking half is part of what makes the claims of property exist in the first place. Note again that it is not true that gatherers have even a pro-tanto claim on their entire 200 berries, which is then overridden on the basis of other principles. ${ }^{3}$ Indeed, the gatherers could move to an entirely collectivised system under which no individual ever had any property claim at all to a berry, in much the same way as no farmer has any claim at all to a piece of common land.

This simplified case is analogous to state taxation on the conventionalist view of property. It is this sense that Murphy and Nagel suggest that taxation cannot, even in principle, violate property rights. The example of the gatherers should be distinguished

\footnotetext{
${ }^{2}$ For discussions of the indeterminacy of libertarian rights see the discussion between Fried (2004, 2005), Otsuka et al. (2005).

3 Many might have intuitions which suggest that the gatherers do at least have some claim to the berries they picked, since they expended labour to get them, but this is just to say that there are at least some good arguments to reject Murphy and Nagel's purely conventionalist view or to think that one important desiderata when deciding between conventions is the extent to which property holdings are proportional to labour expenditure.
} 
from another case where the right to exercise political power is in play. It is of course true, as Tomasi suggests, that our ability to influence political decisions is shaped by convention. For instance, in the U.K. votes are counted by a first-past-the-post system, whereas in Germany votes are counted proportionally. It is therefore true that one's right to influence power is violated if one's vote is not counted in the proportional calculations in Germany, but not true in the U.K. because of the differing conventions. It therefore might seem, as Tomasi suggests, that the right to vote is conventional in the same way as property. However, this is incorrect. This is because citizens have an individual claim to having a say in governance. This claim is theoretically prior to conventions. Our political conventions are supposed to instantiate this claim rather than create it. For this reason, a system which denied citizens the vote is not at all analogous to one which collectivises property.

Therefore, I believe that Murphy and Nagel's argument cannot be dismissed in the way that Tomasi suggests. If one accepts a conventional view of property, it is not true that taxation can violate a property right claim. It is important to note what does, and does not, follow from this. It certainly does not follow that Tomasi's market democracy has been refuted, since there may well be highly plausible reasons to favour conventions which allow private property to those which collectivise property. I will turn to these arguments in the following section. What does follow is that the effect on property rights is not part of the calculus when assessing various possible schemes of taxation ranging from the very low rates of laissez-faire regimes to the much heavier regimes of property owning democracies. Indeed, Tomasi cannot even object to the collectivised economy of a liberal socialism on these grounds, since on this set of conventions no individual could have legitimate claim to the means of production. The task is to work out which property conventions best promote various values, whereas at times Tomasi suggests that an important advantage of market democracy is that it respects property rights, whereas social democratic regimes infringe them. Defending markets on these rights-based grounds is only open to defenders of a pre-societal conception of property. Critically, as we have seen this is a strategy Tomasi rejects.

\section{Undermining the Connection Between Markets and Agency}

In this section I subject Tomasi's claim that market economies maximise the ability of citizens to be responsible self-authors to critical scrutiny. As noted, Tomasi's core claim is that markets provide citizens with more choices then are available under state managed regimes, and that choice promotes someone's agency in the relevant sense.

I will accept that markets do indeed promote choice, but will question whether the kinds of choices promoted by market societies do in fact promote agency in the relevant sense. I will suggest two problems for this link. The first I term valueless agency, which occurs when citizens do indeed have control of some aspect of their lives but not in ways that foster self-authorship. The second problem I term the illusion of agency, which occurs when citizens appear to have control over their lives but do not, a situation which can have seriously detrimental consequences. 


\section{Valueless Agency}

As I noted above, central to Tomasi's defence of free market politics is the fact that markets give individuals an expanded realm of choice in which to shape their economic lives. In this section, I argue that in many cases which are central to economic lives the existence of choice provides no real opportunities to self develop. Instead, these extra choices might frustrate development by taking up the time and mental resources which might otherwise be used on personal projects that do allow individuals to develop their moral powers.

To show an example of choices which do not promote agency, consider the choice of which road to get to a given destination. It might be that the government has only constructed one road, and therefore everyone has to take the same path. No one has any choice to think about before travelling between A and B. Alternatively, it might the case that there are many different roads to take. Some are motorways that get one to the destination quickly but boringly, others go via historic towns, others via areas of natural beauty, and so forth. In this case, there is a choice about how to travel between A and B, and this choice develops and reflects a person's ability to live as an agent, at least to some degree. In a third case, there is only really one road that it is rational to take, but it is just very difficult to find the right one because the maps and road signs are horrendously unclear, let us call this the 'spaghetti junction' option. ${ }^{4}$ While trying to find the right way out of spaghetti junction does indeed involve difficult choices, no one could reasonably be said to have an interest in living such that they are required to make such choices on a regular basis.

Option one in this case represents how Tomasi would like us to think about economic life in a social democratic society. While there are no difficult decisions to make about pensions and healthcare, the very lack of these decisions denies citizens the ability to shape an important part of their lives. He therefore commends market societies as being more like option two. Market societies offer a variety of occupational choices and choices about how to structure healthcare, education and pensions in ways that develop and express a person's considered choices. To illustrate the sense in which economic decisions might be linked to personal projects in this way, Tomasi offers the rich example of Amy, a small business owner. Amy we are told is a college dropout who has an entry-level job as a pet groomer:

Dreaming of owning a business of her own, Amy saves her money, builds a sterling credit rating, wins a bank loan, and finally opens her own pet shop (Amy's Pup-in-the-Tub). What does it mean to Amy to walk into her shop each morning, or, when leaving after a particularly long day, to look back and read her name up on the sign? (Tomasi 2012, p. 66).

This example is compelling, and highlights a serious worry with many existing conceptions of liberal egalitarian justice. It seems highly implausible for defenders of social democratic conceptions of justice to deny the existence of a serious moral cost if small scale entrepreneurial decisions like Amy's are prohibited. Of course, this does not settle the argument in favour of allowing the existence of small

\footnotetext{
${ }^{4}$ For foreign readers, this refers to a notoriously confusing and overcrowded junction in the U.K.
} 
businesses. Defenders of highly statist approaches might suggest that the egalitarian benefits of communal ownership outweigh the loss to prospective entrepreneurs. It is also worth pointing out that defenders of left-wing proposals such as Universal Basic Capital or property-owning democracy often emphasise the fact that these schemes might promote people's abilities to run a small business. Nevertheless, Tomasi has offered a powerful argument in favour of a specific set of economic liberties, despite the inequality of resources these liberties may produce.

However, what is more in doubt is his belief that this kind of freedom extends to decisions about provision of important goods such as healthcare or pensions. Tomasi again suggests that financial decisions have a vital link to agency, he writes:

Questions about long term financial planning require that people think seriously about the relation between the person that each is at one moment to the person one will become many years in the future.... Economic decisions require that people assess their most basic values, and in light of this assessment, set themselves on a course of life that is their own (Tomasi 2012, p. 80).

In contrast, I suspect that in many cases financial freedom is more like the spaghetti junction alternative. Consider the American experience of 401(k) retirement plans (see for instance Mottola and Utkus 2003). A 401(k) refers to a move towards a more privatised system in which employees invest their funds in a personal pot. This move has certainly expanded the choices available to savers. They can invest in shares, foreign currency and a variety of other inventive financial products. However, a Schwab (2014) U.S. national survey found serious confusion amongst citizens about how 401(k)s operate. Finally, no discussion of 401(k)s would be complete without noting their catastrophic decline in value during the recent economic downturn. ${ }^{5}$ Again, an important part of this story is that individuals simply had no idea that they were risking their retirement plans in this way. The same Schwab (2014) survey suggested that a large proportion of savers had no idea their money was at risk, instead believing that expected pay-outs were somehow guaranteed.

For our purposes, this matters for two reasons. First it reinforces the extent to which citizens' did not understand their options. Presumably citizens who do not understand their choices cannot possibly be expressing or developing their moral powers by making them. Second, the evidence suggests what citizens really want in this case is whatever options gets a guaranteed pay-out. People did not want to take a risk with their retirement, but many were doing just that. To somewhat force this example into my analogy, the vast majorities they want the motorway to a minimum pension but cannot find the way onto this because of the complexity in the system.

In many ways, the above problems might be thought to be specific to various schemes, and thus defenders of market conceptions are entirely at liberty to simply argue in favour of a better designed privatised market. Tomasi and others would also wish to point to several serious failures with government-run approaches. However, these various problems point to deeper features of privatised services. Many choices about healthcare, pensions and other services provided by social democratic states

\footnotetext{
${ }^{5}$ See, for instance, VanDerhei (2009). This estimates $25 \%$ losses for those with average to large style 401(k) accounts.
} 
are highly complex and technical. It is true that there are many decisions about healthcare which express a person's goals and plans, for instance whether to have surgery to preserve sports functioning that risks future mobility or how to structure lifetime consumption through pensions versus current consumption. But many decisions do not have this character. In standard health cases, the patient will simply wish to cure a specific illness or complaint, likewise many individuals will simply want to ensure they have a pension that guarantees a reasonable minimum. The complexity comes in achieving these ends. In his classic essay, 'Uncertainty and the welfare economics of medical care' Arrow (1963) noted the asymmetric information possessed by consumers of healthcare and by its providers (doctors/hospitals and insurance companies). In the healthcare cases, expert knowledge is often required to make even basic judgements about what is required. In addition, patients are not often in the best frame of mind to make a cool and calculated decision about what level of care to buy. This might be because they are currently impaired, or because of the emotional importance of healthcare, few would haggle with a doctor over the cost of their child's treatment. Thus, decisions about healthcare are often not a vehicle for self-development. Instead they are deeply stressful choices made without adequate information, and the predictable effect of individualising them is to make most individuals worse off.

In light of these various considerations, I believe there is a strong case to be made that many individuals' ability to be a responsible self-author is promoted by taking away significant choices about healthcare, savings and pensions (and indeed many other decisions). This is because individual choice about provision of these basic services promotes valueless agency. Citizens genuinely do have choices, but these choices are just about how to navigate a complex and potentially risky option set. Removing many of these decisions from citizens would in fact promote, rather than hinder, citizens' abilities to make choices that really do reflect their values and conceptions of the good.

To illustrate, return to Tomasi's example of Amy. Consider the differences in Amy's story in cases where she lives in a laissez-faire economy, as opposed to a mixed economy with government provision of many key services. Amy will have to purchase insurance for her business, and given it is the source of her income her pension and healthcare will depend largely or entirely (depending on the specifics of the market regime in question) on her businesses success. This, I contend, is likely to raise the stakes of her decision in ways which are deeply uncomfortable for Amy. Indeed, the fact that in a market economy one's ability to provide a pension and healthcare depend upon one's success might well diminish the attractiveness of starting up a business for small time entrepreneurs like Amy. After all, the reason one would have a safety net is to encourage risk taking like walking a tightrope. Indeed, it is notable that the numbers of start-up businesses is lower in the U.S. than countries with more expansive welfare systems such as Britain, Israel, and Canada (Wimberley 2011). Being forced to control her health insurance and retirement plan might also undermine her ability to run her business. As I noted above, decisions about how to invest for the future and providing healthcare choices are complex. Every day spent sorting these issues is one less day that Amy is spending controlling the features of her business that really reflect her own preferences and values. 
Another important aspect of failures of privatised healthcare and pensions is that outcomes are, almost invariably, worst for the worst off. Returning to my examples drawn from America above, it is those who are poor, self-employed or those that have pre-existing conditions who have fared worse in the current semi-privatised system. This is evinced in comparative charts of care, showing that while some in the U.S. enjoy the very best levels of healthcare, the worst-off fare worse than individuals in other OECD countries that have a social safety net (Pear 2008). This differential care has serious consequences, the gap between the life expectancy of the richest quintile versus the poorest has grown significantly over recent years, and is now almost a decade. ${ }^{6}$ Indeed, significantly given Tomasi's argument, the life expectancy of the very worst off groups has shown almost no increase over the past decades, a scenario not replicated in countries with more egalitarian healthcare arrangements (Tavernise 2012).

The tendency for privatised safety nets to do badly for the worst-off follows from some deep-rooted aspects of their situation in our society. Most obviously, the worst-off lack resources, and healthcare and pensions are expensive. More subtly, the worst-off in society tend to have a lower quality education than those more privileged. Given, as I argued above, success in privatised systems requires the ability to acquire and process a large amount of complex data, these kinds of information inequalities are extremely worrying. The fact that the worst-off are likely to bear the brunt of the downsides of privatisation is deeply problematic for Tomasi given the broadly Rawlsian framework he adopts. In particular, he accepts the principle that inequalities are only justifiable if they are to the advantage of the worst-off. If the worst-off will predictably lack the resources, information and skills to benefit from the privatisation of key services he would therefore be committed to allowing the state to run these institutions.

\section{The Illusion of Agency}

In this section, I outline a further reason to be sceptical of Tomasi's claim that markets develop the moral powers of citizens. I refer to this problem as the illusion of agency. By this, I refer to cases in which society and the individual in question treat choices as resulting from an agent's control, but in fact this is not the case. I will suggest that this kind of illusion of agency is common within current liberal societies and would be even more pronounced in various kinds of market democratic society outlined by Tomasi. I believe the illusion of agency to be a general problem with Tomasi's account, but will outline my argument through a consideration of his discussion of equality of opportunity.

When outlining Rawls' principle of Fair Equality of Opportunity (FEO), Tomasi correctly suggests that this principle allows inequalities so long as they are to the benefit of the worst-off. This draws on an often unnoticed part of Rawls' account, in which he qualifies the two principles in light of various constraints. Thus, whereas the most often quoted version of FEO states that 'social and economic inequalities

\footnotetext{
${ }^{6}$ A particularly striking trend is the large gaps in life expectancy of males between those of low income and high income. See Deaton (2003), p. 117.
} 
are to be arranged so that they are attached to offices and positions open to all under conditions of fair equality of opportunity' (Rawls 1973, p. 83, 302), the qualified version is altered to 'an inequality of opportunity must enhance the opportunities of those with the lesser opportunity' (Rawls 1973, p. 303). This is, on the face of it, a significant revision. The first statement, which we might refer to as the strict egalitarian reading of FEO would prohibit any basic structure in which certain social classes predictably had more opportunities than others. The second, maximin, reading of FEO would in principle permit very wide inequalities of opportunity provided all were to the benefit of the worst off. ${ }^{7}$

After making this theoretical distinction, Tomasi offers several arguments to show how, on this maximin conception, a variety of market democratic conceptions could be shown to be compatible with the requirements of FEO (see Tomasi 2012, pp. 237-247). Most significantly, the possibility of economic growth allows the creation of many more opportunities than is possible in a stagnant economy. Further, rising incomes gives workers more power to bargain about their job conditions and role in the firm.

One possible, and I believe at least partially correct, response to Tomasi's arguments is a broadly empirical one. We should note that while economic growth does indeed tend to produce resources and a widening variety of jobs and other occupations, these advantages do not in our world tend to flow to the least advantaged in society. Instead, current economic trends have created a large class of people working highly routine and monotonous jobs in the service sector. These jobs are often low paid, with the result that the real wage of the lowest earners is in fact remaining constant or perhaps decreasing. ${ }^{8}$

However, I believe there are deeper reasons to object to Tomasi's view. Specifically, I believe that Tomasi's account would create a serious problem of illusory agency for the worst-off. To show this, imagine a society in which equality of opportunity (on the egalitarian conception) was perfectly realised. In this society, it would therefore be true that any two individuals of similar ability would have an equal chance of achieving any particular desirable position. As defenders of the egalitarian conception of FEO recognise, this ideal is more or less impossible in practice. The most significant obstacle would appear to be the existence of tight-nit family units. Rawls himself writes that 'It seems then that even when FEO is satisfied, the family will lead to unequal chances between individuals' which prompts him to ask the question 'is the family to be abolished then?' (Rawls 1973, p. 511). For the sake of argument though, imagine a society in which not only was FEO perfectly realised, but that (even more implausibly) all instances of bad brute luck that might affect an individual's job chances had been eliminated.

One significant virtue of this society would be that every citizen would know that their particular place in the economic scheme could be traced back to either their own decisions or their own talents. ${ }^{9}$ This connection between choices and results is

\footnotetext{
7 This distinction is explored in detail by Pogge (1989).

8 See for instance the U.K. government report that notes an increase in employment both in the higher paid end of the spectrum and an even more marked increase towards the lower end (Mcintosh 2013).

9 Indeed, given the relatively arbitrary nature of talents some bioethicists suggest that to ensure that citizens are truly responsible for one's place in a hierarchy the state should equalise natural inequalities as well. See, for example, Feeney (2006).
} 
of significant value in developing those individuals' abilities to be self-authors. Those individuals who are successful, and who hold desirable positions, can look back and see the importance of earlier choices which directly led to their current status. Even those individuals who would rather have different jobs benefit from this kind of equality of opportunity. They can trace their position back to their own choices and must come to accept responsibility for their lives.

Contrast a society with egalitarian FEO with a market democratic society in which there is much more luck involved in getting the very best positions. This luck would be introduced in several forms, and would depend in part upon the precise character of the market regime in question. Most obvious is parental income. As I noted earlier, a robust body of research indicates that parental income is a strong predictor of entrance into elite colleges and other desirable positions. Another way luck will enter the system is through the choices of employers. In most social democratic conceptions, strict laws exist designed to ensure that employers only act on the basis of job-specific criteria. These laws are often criticised from the Right on the grounds of restricting the liberty of firms to hire as they wish, a critique Tomasi broadly endorses. On a market democratic conception these protections would be correspondingly weaker. He writes that:

The regime type I call democratic laissez-faire, by contrast, relies more purely on the market in pursuit of the good of formal equality of opportunity. Under that regime type, business owners have wide freedom to hire and promote workers by whatever criteria they choose-even when such decisions may reasonably be said to be based on race, gender, religious beliefs, sexual orientation, or aesthetic judgements about a person's 'looks' (Tomasi 2012, p. 241).

Two important features of this conception are that, firstly citizens might lose out on a job opportunity for reasons not even remotely under their control (such as their race or gender), and second, the wide variety of permissible reasons for not being hired means that citizens will not know on what grounds they failed to get the job, and whether these reasons were connected to their ability to do the job even in the ideal case.

To show the importance of this concern with market democracy, imagine someone much like Amy, but whose economic projects require many more competitively awarded grants or positions. Amelia wishes to become a dentist and open her own studio catering to a specific condition that she herself suffered with as a child. She is also a member of the worst-off group in society. Just as with Amy, we can see a close connection here between Amelia's economic goals and her conception of self and on-going projects. However, unlike Amy, Amelia's life plan requires she wins various competitions before she can achieve her goals. There are very good reasons to require dentists to have a long training period, and also to ensure that dentists have sufficient skill and ability. This implies that dental training will be apportioned by some kind of process, and individuals cannot simply choose to set up a successful dental practice in the way that Amy set up her pup in the tub store. Now imagine that Amelia, living in a market democratic society, failed in her life plan. She might have not been admitted to college, or failed to do well enough 
there to get follow-on dental training, or perhaps she was unable to pay for the long training contract and failed to get one of the private bursaries available.

How must Amelia look back on her failure? It might be that her failing in her life goal is her own responsibility, and could have been rectified by harder study. However this is very far from certain. It might be true that Amelia's school was considerably worse than others on offer, perhaps for financial reasons, and thus that she never really stood a chance in the application procedure to university. It might also be true that the amount of money her parents had was more directly important, perhaps because the private university had an incentive to accept richer students who would donate more. It might be that she did not get the job because many of the committees involved were racist or misogynist in some way. She might not have got her dream job because a dentist who was hiring found another candidate more attractive and hired her on this basis.

The existence of unequal schooling and laissez-faire hiring thus seriously limits the sense in which Amelia is able to understand and (at least in principle) have altered the causes of significant events in her life. I believe that this uncertainty about the relevant reasons for hiring is itself undermining of Amelia's ability to live as a responsible self-author and develop her moral powers. One important part of agency is knowing what were the causes of significant events within one's life, and understanding how one might have acted differently (and should act differently should similar circumstances occur again).

Tomasi himself recognises this link. When discussing the moral power of the Rational, he writes that 'People are life agents and their agency matters. As responsible-self authors, they have the capacity to realistically assess the options before them, and in light of this assessment, to set standards for a life that each deems worth living' (Tomasi 2012, p. 40). The importance of realistic assessment is critical here. I believe that in our world (and perhaps particularly in the U.S.) many citizens have highly unrealistic assessments of their options. One important reason is that, culturally, many believe in a more egalitarian conception of equality of opportunity and believe that this kind of equality exists in their own society. The thought that anyone can succeed provided they are willing to work hard is essence of the so-called 'American Dream.' These beliefs are at stark odds with the actual chances of circumstances of life for many citizens. For instance, the Sutton Trust reports that upward mobility is relatively low in the U.S. compared to many other European countries (with the exception of the U.K.). Their 2008 report argues that the data suggests that 'those at the bottom of the income ladder in early life are far less likely to earn higher incomes as adults when compared with children from richer homes' (Sutton 2008, p. 1).

This discrepancy between believed opportunities and actual opportunities is deeply problematic for the development of the moral powers, since it undermines the extent to which citizens' lives are being lived on the basis of a realistic assessment of their actual options and their prospective chances of success in these options. Given her (relatively, if not absolutely) bad start in life and the inegalitarian nature of her society, Amelia's plans of becoming one of the few dentists in her society are thus not realistic enough to count as a development of her moral powers. 
How might Amelia be compensated for this lack of opportunity and corresponding ability to develop as a self -author? One way is through resources, but we have seen that this is insufficient to meet the requirements of FEO, even on the maximin reading. Instead, Tomasi argues that a combination of economic growth and a pluralistic labour market will provide even the losers with more opportunity than they would have had in a more heavily state-run economy. In Amelia's case it might be true that the various jobs open to her without a college degree are of a much higher quality and interest than they would have been in a stagnant state-run economy. However, this does not seem like the optimum scenario for Amelia. After all, her conception of the good led her to want to be a dentist. Even if other options are just as rewarding from some objective point of view they would not be as rewarding for Amelia. The choice is one between a social democratic World A in which Amelia has a fair chance at achieving her dream of being a dentist, versus a market democratic World B in which she has an even better chance of achieving her dream of getting some improved lower wage job "janitor + '. In both worlds, we can reasonably imagine that Amy would desire to become a dentist, thus in World B her compensatory opportunities will always be second bests, and Amelia will believe that she failed in her dream due to mistakes, or that she was not sufficiently talented.

If accurate, this suggests that market democracy faces an unpleasant choice. It can support stark inequalities of opportunity (that benefit the worst-off) and a culture of aspiration, but accept that many citizens like Amelia will live lives full of disappointment and have a problematically misguided understanding of their real opportunities. Alternatively, it could try to take measures to ensure that those from poorer backgrounds had diminished aspirations and more realistically made plans based on the (near) certainty of them being able to achieve only a limited range of jobs. This option would reinforce the ability of worse-off citizens to have a realistic assessment of their options, but would presumably carry severe costs. This kind of society, in which many citizens of ability and talent knowingly accept their diminished opportunities, surely violates the spirit, if not the letter, of justice as fairness. More significantly, it is a society which seems profoundly unattractive.

The problems faced by Amelia above demonstrate the problem of the illusion of agency. She believed her place in the overall social hierarchy would be responsive to her own effort, but in fact her success or failure was determined by her parent's income, her race, gender or sexual attractiveness. I suggested that she was in many respects worse off than someone who accepted that her abilities to succeed were not under her control. Belief that she was the cause of her success inevitably means that she falsely believes she was the cause of her own failure. This might imply that she believes it is legitimate for others to treat her as a failure in ways that are clearly wrong given she had little control over events. This kind of illusion of agency occurs frequently within capitalist economies. People with high incomes routinely act as if they must have done something to earn these rewards relative to the unemployed, but in many cases their different incomes can be traced entirely back to shifts in the economy and unpredictable changes in consumer demands. This worry is in a sense inevitable. In no society will success be entirely controlled by the agent, but they do suggest a compelling reason to try and link success to choice, and 
I have suggested this in turn gives a reason to favour egalitarian educational institutions and much stricter control of the labour market than Tomasi favours.

\section{Conclusion}

This paper has only considered a small selection of the various rich arguments Tomasi offers in defence of market democracies. It therefore cannot be taken as a full defence of the more traditional welfare state against his critique. I have, though, suggested that Tomasi's characterisation of free market societies and their connection to political agency is defective in certain respects. In particular, I have attempted to undermine the picture of economic choices as one which necessarily promotes an individual's ability to live in accordance with a plan of life they have devised. Some economic choices really do spring from an individual's conception of themselves in this way. However, many other economic choices do not have this character. Instead, choices can be deeply confusing and made under conditions in which many agents will lack sufficient understanding to properly select their goals. This valueless agency means that citizens in a free market will have to spend valuable time trying to secure basic necessities instead of spending time pursuing their own projects. Worse, in many free market societies individuals will believe themselves to be responsible for much more of their circumstances than is really true. This illusion of agency undermines their ability to properly understand and alter their circumstances.

Open Access This article is distributed under the terms of the Creative Commons Attribution 4.0 International License (http://creativecommons.org/licenses/by/4.0/), which permits unrestricted use, distribution, and reproduction in any medium, provided you give appropriate credit to the original author(s) and the source, provide a link to the Creative Commons license, and indicate if changes were made.

\section{References}

Arrow, Kenneth. 1963. Uncertainty and the welfare economics of medical care. The American Economic Review 53: 941-973.

Charles, Schwab. 2014. 401(k) participant survey. Schwab Retirement Services. http://aboutschwab.com/ images/uploads/inline/deck_2014-Schwab-401(k)-Participant-Survey.pdf. Accessed 30 Apr 2014.

Cohen, Gerald A. 1986. Self-ownership, world ownership, and equality: Part II. Social Philosophy and Policy 3: 77-96.

Deaton, Angus. 2003. Health, inequality, and economic development. Journal of Economic Literature 41: $113-158$.

Feeney, Oliver. 2006. Equality of whom? A genetic perspective on equality (of opportunity). Res Publica 12: 357-383.

Fried, Barbara H. 2004. Left-libertarianism: A review essay. Philosophy and Public Affairs 32: 66-92.

Fried, Barbara H. 2005. Left-libertarianism, once more: A rejoinder to Vallentyne, Steiner, and Otsuka. Philosophy and Public Affairs 33: 216-222.

Locke, John. 2008 [1690]. Second treatise of government. New York: Seven Treasures.

McIntosh, Steve. 2013. Hollowing out and the future of the labour market. In BIS research paper number, 134. Department for Business, Innovation and Skills. http://www.gov.uk/government/uploads/ system/uploads/attachment_data/file/250206/bis-13-1213-hollowing-out-and-future-of-the-labourmarket.pdf. Accessed 15 Sept 2015. 
Mottola, Gary and Stephen Utkus. 2003. Can there be too much choice in a retirement savings plan? Vanguard Center for Retirement Research. http://www.403bwise.com/pdf/vcrr_choice_study.pdf. Accessed 30 Apr 2014.

Murphy, Liam, and Thomas Nagel. 2002. The myth of ownership: Taxes and justice. New York: Oxford University Press.

Nozick, Robert. 1974. Anarchy, state and utopia. New York: Basic Books.

Otsuka, Michael. 2005. Libertarianism without inequality. Oxford: Oxford University Press.

Otsuka, Michael, Peter Vallentyne, and Hillel Steiner. 2005. Why left-libertarianism is not incoherent, indeterminate, or irrelevant: A reply to Fried. Philosophy and Public Affairs 33: 201-215.

Parfit, Derek. 1997. Equality and priority. Ratio 10: 202-221.

Pear, Robert. 2008. Gap in life expectancy widens for the nation. New York Times. http://www.nytimes. com/2008/03/23/us/23health.html?_r=0. Accessed 30 Apr 2014.

Pogge, Thomas. 1989. Realizing rawls. Ithaca: Cornell University Press.

Rawls, John. 1971. A theory of justice. Cambridge: Belknap Press.

Rawls, John. 1973. A theory of justice. Oxford: Oxford University Press.

Shields, Liam. 2012. The prospects for sufficientarianism. Utilitas 24: 101-117.

Steiner, Hillel. 1977. Justice and entitlement. Ethics 87: 150-152.

Sutton Trust. 2008. Social mobility and education. http://www.suttontrust.com/wp-content/uploads/2009/ 09/academic_papers_report.pdf. Accessed 30 Apr 2014.

Tavernise, Sabrine. 2012. Life spans shrink for least-educated whites in U.S. New York Times. http:// www.nytimes.com/2012/09/21/us/life-expectancy-for-less-educated-whites-in-us-is-shrinking.html? pagewanted=all\&_r=0. Accessed 30 Apr 2014.

Temkin, Larry. 2003. Equality, priority or what? Economics and Philosophy 19: 61-87.

Tomasi, John. 2012. Free market fairness. Princeton: Princeton University Press.

VanDerhei, Jack. 2009. The impact of the recent financial crisis on 401(k) account balances. Employee Benefit Research Institute Issue Brief 326. http://www.ebri.org/pdf/briefspdf/EBRI_IB_2-2009_ Crisis-Impct.pdf. Accessed 30 Apr 2014.

Wimberley, James. 2011. Safety-nets: hammocks or trampolines? http://www.samefacts.com/2011/10/ international-affairs/europe/safety-nets-hammocks-or-trampolines/. Accessed 30 Apr 2014. 